\title{
IbM KELOMPOK WANITA NELAYAN TIANYAR TIMUR
}

\author{
Ni Ketut Sari Adnyani \\ Jurusan Pendidikan Pancasila dan Kewarganegaraan, Fakultas IImu Sosial \\ Universitas Pendidikan Ganesha \\ e-mail: sariadnyani@yahoo.co.id
}

\begin{abstract}
Abstrak
Tujuan utama kegiatan pengabdian kepada masyarakat melalui program Ipteks bagi Masyarakat (lbM) ini adalah untuk: 1) Meningkatkan pemenuhan taraf kesejahteraan masyarakat pesisir terkait dengan keberadaan hasil tangkapan ikan yang diharapkan mampu menopang kehidupan anggota kelompok. 2) Meningkatkan penciptaan lapangan pekerjaan baru, ditinjau dari segi pelaksanaannya dapat menyerapan tenaga kerja lebih meluas dan diorganisir sesuai kesepakatan dan ketentuan bersama. 3) Meningkatkan kemampuan bekerjasama dalam kelompok, Kelompok Wanita Nelayan Tianyar Timur yang di dalamnya tergabung kumpulan wanita nelayan mengorganisir anggotanya untuk bekerjasama sesuai dengan kesepakatan dan ketentuan bersama untuk membangun program wirausaha mandiri dari kalangan perempuan pesisir, dan terdapat pula pembagian tugas yang jelas dalam kelompok yang diatur dan disepakati melalui ketentuan bersama. 4) Menyediakan wadah pemasaran produksi yang sifatnya koordinatif melibatkan kelompok wanita nelayan termasuk menginventarisasi jenis sarana dan prasarana pendukung yang akan diperlukan dalam pemasaran ikan sehingga dapat melahirkan usaha bersama kelompok (UBK) yang sifatnya rintisan; dan 5) Meningkatkan target sasaran marketing programme, pemasarannya dapat dikategorikan dalam 2 jenis, yaitu berupa bahan baku tangkapan dan olahan kuliner. Untuk kepentingan pencapaian tujuan program ini, maka dilakukan model pendampingan pengurusan SIUP merupakan kombinasi kegiatan antara bidang hukum, tata boga dan budidaya kelautan, serta keseluruhan proses transfer iptek yang telah dilaksanakan dengan pola pelatihan maupun pendampingan kepada wanita nelayan desa Tianyar Timur dan pengelolaan manajemen usaha secara terpadu dan terarah sehingga peserta pelatihan mendapatkan informasi yang jelas dan utuh mengenai hakekat pemberdayaan masyarakat dari segi pengetahuan dan keterampilan pengelolaan komoditi pesisir secara produktif dan tepat guna. Pelaksanaan program dikemas dalam 3 (tiga) tahapan yakni: alur pelaksanaan program IbM ini dimulai dari, 1) Tahap persiapan, 2) tahap pelaksanaan, dan 3) tahap evaluasi. Hasil kegiatan menunjukkan tingkat partisipasi yang tinggi dari mitra dalam pelaksanaan pelatihan dan pendampingan Tata Boga, diklat pengelolaan kawasan pesisir bagi nelayan, serta pengurusan ijin usaha perdagangan (SIUP).
\end{abstract}

Kata Kunci: Kawasan Pesisir, Komoditi Hasil Tangkapan Ikan, Olahan Kuliner, SIUP, Tata Boga,Wanita Nelayan.

\begin{abstract}
The main purpose of community service activities through science and technology program for the Community ( IbM ) is to : 1 ) Increase the fulfillment of the welfare of coastal communities associated with the presence of fish is expected to sustain the lives of group members. 2 ) Increase the creation of new jobs, in terms of implementation can absorb labor is more widespread and organized according to agreement and consensus . 3 ) Improve the ability to cooperate in a group, Women Group Fishermen East Tianyar in which incorporated women's groups organized fishermen members to cooperate in accordance with the provisions of the collective agreement and to establish an independent entrepreneur program from among the women of the coast, and there is a clear division of tasks within the group arranged and agreed upon by consensus . 4) Provide marketing container production coordinative nature involve groups of women sailors including an inventory of the types of facilities and supporting infrastructure that will be needed in the marketing of fish that can produce joint venture group (UBK) that are longer ; and 5) Enhances target marketing program, marketing can be categorized into two types, namely in the form of raw materials and refined culinary arrests. For the purpose of achieving the objectives of this program , then do facilitation model is a combination of Company management activities between legal field, culinary and mariculture, as well as the overall transfer process and technology that have been implemented with training and mentoring scheme for women fisherman village of East Tianyar and management efforts integrated and coherent so that trainees get a clear and complete information about the nature of community empowerment in terms
\end{abstract}


of knowledge and skills to manage commodity productive coastal and appropriate . Program implementation is packaged in three (3) phases namely : groove execution of this program starting IbM , 1) Level of preparation , 2) implementation, and 3) the evaluation phase. Activity results show high levels of participation of partners in the implementation of training and mentoring Catering , coastal zone management training for fishermen, as well as the management of commercial business license ( original).

Keywords: Coastal area, Commodities catch fish, Processed Culinary, License, Catering, Women Fishermen

\section{PENDAHULUAN}

Daerah pesisir biasanya identik dengan komoditi hasil laut, salah satunya hasil tangkapan ikan untuk konsumsi sehari-hari. Kendala yang dihadapi oleh masyarakat Desa Tianyar Timur yang menggeluti pekerjaan sebagai nelayan adalah mengalami kesulitan dalam pemasaran ikan dalam jumlah yang banyak pada saat musim panen ikan laut tiba.

Mitra dalam kegiatan pengabdian pada masyarakat (P2M) ini yaitu wanita nelayan di Desa Tianyar Timur, yang diantaranya menggeluti pekerjaan: pertama sebagai penyadang ikan sekaligus pedagang ikan; kedua, wanita nelayan yang mengelola kuliner; ketiga, wanita nelayan yang bersedia menggunakan tempatnya sebagai wadah pemberdayaan program diklat P2M dengan maksud dikembangkan sebagai warung lesehan Keberadaan wanita nelayan sangat menunjang keberhasilan pemasaran hasil panen ikan di Desa Tianyar Timur. Berbagai strategi dikerahkan oleh para wanita nelayan, termasuk salah satunya Ni Ketut Sayang yang menggeluti pekerjaan sebagai pedagang ikan. Mitra pertama Ni Ketut Sayang merupakan istri nelayan yang memiliki sebuah perahu yang dipakai untuk melaut. Dengan hasil yang tidak menentu akhirnya lbu ketut mencoba membantu perekonomian keluarga dengan menjadi tukang cadang ikan (pengepul kecil). Secara finansial keuntungan nelayan tipis karena perbandingan harga eceran jauh lebih stabil dan menguntungkan, harga ikan dipasaran untuk jenis ikan awan dan suat misalnya: \pm Rp.5.000,- s/d Rp.7.000,- per ekor, klasifikasi harga ini biasa dipatok wanita nelayan menurut besar kecilnya jenis ikan. Daripada menjual dengan harga borongan yang sangat jauh lebih murah pasarannya rata-rata ikan dihargai \pm Rp.3.000,- secara borongan atau istilah lokalnya nyaruk atau dibeli dengan cara borongan. Hal ini membawa pengaruh besar terhadap terhambatnya pemenuhan taraf kesejahteraan kelompok nelayan setempat. Mitra kedua, Nyoman Sumiati menggeluti profesi pedagang kuliner hasil olahan laut. Rutinitasnya yakni membuat barang dagangan dalam jumlah yang terbatas sesuai dengan perkiraan kemampuan memasarkan. Pemasarannya hanya dari rumah ke rumah dengan cara menjajakan ke setiap keluarga. Jadi, dinilai penting melalui usulan program P2M ini ada yang mengkoordinir kelompok wanita nelayan sehingga mereka memiliki wadah untuk memasarkan produk kuliner pesisir. Mitra ketigalbu Ni Kadek Putus Asrini, memiliki keinginan besar untuk mengubah usaha yang dimilikinya untuk usaha kuliner yang lebih menjanjikan.

Kegiatan IbM Kelompok Wanita Nelayan Tianyar Timur perlu diproduktifkan dengan mendayagunakan kinerja wanita nelayan untuk jenis masakan siap saji secara produktif dalam pengembangan usaha kuliner dengan menu utama hasil olahan laut. Keseluruhan proses transfer iptek yang telah dilaksanakan dengan pola pembinaan keterampilan dan pelatihan serta pendampingan yang meliputi: tata boga dengan pemanfaatan komoditi kawasan pesisir, dan rancangan pengurusan SIUP UBK. Tujuan pelaksanaan P2M IbM Kelompok Wanita Nelayan Tianyar-Timur adalah menunjang pengembangan produktifitas produksi industri rumah tangga dari wanita nelayan yang berupa hasil tangkapan mentah maupun olehan kuliner yang 
pemasarannya bisa dilakukan secara terorganisir oleh kelompok wanita nelayan yang sifatnya kolektif, diantaranya dapat berupa: 1).Mendukung kehidupan masyarakat pedesaan khususnya kawasan pesisir Desa Tianyar Timur dengan meningkatkan kesempatan kerja, menyediakan penghidupan yang layak dan mantap bagi wanita nelayan, termasuk kelompok nelayan. 2).Meningkatkan produksi dan menjamin keamanan pangan dengan bahan dasar ikan laut di wilayah Desa Tianyar Timur. 3).Menghasilkan pangan yang terbeli dengan kualitas nutrisi tinggi dan 4).Melestarikan dan meningkatkan kualitas hidup di kawasan pesisir dan pedesaan Desa Tianyar Timur serta melestarikan sumber daya alam dan keanekaragaman hayati laut.

\section{SUMBER INSPIRASI}

Berdasarkan kemajuan yang dicapai oleh Secara riil mereka memiliki gagasan ingin mendirikan warung lesehan dengan menu sajian kuliner Segara/laut. Perempuan pesisir ini telah mendapatkan ilham dari keberhasilan lesehan-lesehan yang ada di Kawasan lalu lintas Gowa Lawah. Hampir sebagian besar di tepi kanan dan kiri jalan terdapat lesehan yang menyajikan menu kuliner laut dan kalau dipantau konsumen sangat tertarik dan bahkan menjadikan olahan laut sebagai makanan kegemaran.

Berdasarkan observasi di lapangan dari tim pengusul P2M, ditemukan ciri khas yang berbeda dari cita rasa masakan yang disajikan kalau di kawasan Gowa Lawah walaupun pada dasarnya samasama enak dan nikmat, perbedaannya, yaitu: bahwa olahan di desa Pesinggahan cenderung lebih terasa manis, namun di Desa Tianyar Timur olahannya memiliki cita rasa lebih pedas dengan rasa hangat di lidah dan cita rasa yang merakyat. Adonan kuliner laut desa Tianyar Timur sangat khas yaitu mengedepankan campuran rempah-rempah kuat dalam setiap racikan justru menunjukkan sisi perbedaan cocok untuk semua lidahidah

Sasaran produk dalam usulan P2M yang perlu diproduktifkan keberlangsungannya, adalah bidang keahlian pengolahan dari kelompok wanita nelayan, berdasarkan identifikasi studi lapangan di atas, bahwa bidang keahlian yang dimiliki oleh perempuan pesisir belum mendapatkan wadah penyaluran untuk mendirikan usaha lesehan yang tujuannya ingin mendayagunakan produktifitas kinerja wanita nelayan untuk jenis masakan siap saji secara produktif dalam pengembangan usaha kuliner dengan menu utama hasil olahan laut yang beraneka ragam tersebut.

Maka dari itu, rancangan program P2M yang diusulkan direncanakan dengan upaya dari tim pengusul untuk menggandeng mitra yang dimintakan kesediaannya untuk memfasilitasi dari segi tempat dengan memanfaatkan warung kosong yang dimilikinya untuk dikembangkan sebagai warung usaha kuliner mengingat lokasinya sangat strategis tepat di jalur pinggir jalan raya Singaraja-Amlapura. Efektifitas pertimbangan biaya juga tidak memungkinkan untuk mendirikan warung karena harus dipertimbangkan juga operasional kegiatan dari P2M ini, untuk itu tim pengusul mencoba untuk memanfaatkan lahan yang ada dari salah satu perwakilan wanita nelayan Ni Kadek Putus Asrini dijadikan mitra pengembangan usaha kuliner sekaligus sebagai koordinator untuk kelompok wanita nelayan membuka warung lesehan.

Kendala lain adalah modal yang minim dan kesulitan yang dialami wanita nelayan dalam mengurus pinjaman karena masih awamnya pengetahuan dan pemahaman mereka dalam hal mengurus surat ijin usaha perdagangan (SIUP) untuk mendirikan usaha dagang yang menggunakan ijin. Jadi, pemerintah desa juga mengalami kendala mengidentifikasi tingkat kepentingan warganya dalam pengembangan usaha kreatif. Jenis ikan yang umumnya potensial dijadikan olahan kuliner oleh wanita nelayan desa Tianyar Timur adalah ikan Cakalan (Tuna). Selain itu, pemanfaatan limbah tulang ikan yang belum banyak diketahui oleh masyarakat, padahal memiliki kandungan kalsium tinggi. Keterampilan membuat tepung ikan dari tulang ikan tuna akan dengan kemasan berlabel sebagai produksi kelompok wanita nelayan Desa Tianyar 
Timur juga direncanakan bisa seiring dilatihkan dalam kegiatan diklat pada usulan program P2M.

Mitra dalam kegiatan pengabdian pada masyarakat (P2M) ini yaitu wanita nelayan di Desa Tianyar Timur, yang diantaranya menggeluti pekerjaan: pertama sebagai penyadang ikan sekaligus pedagang ikan; kedua, wanita nelayan yang mengelola kuliner; ketiga, wanita nelayan yang bersedia menggunakan tempatnya sebagai wadah pemberdayaan program diklat P2M dengan maksud dikembangkan sebagai warung lesehan Keberadaan wanita nelayan sangat menunjang keberhasilan pemasaran hasil panen ikan di Desa Tianyar Timur.

Berdasarkan analisis situasi dari permasalahan yang dihadapi mitra, maka permasalahan yang mendapat prioritas yang harus ditangani adalah sebagai berikut:

Permodalan dan Home Industry (industri rumah tangga) yang terdiri dari; pemasaran marketing programme ikan mentah, pengurusan ijin, tata kelola usaha kuliner lesehan dan pemanfaatan komoditi hasil tangkapan ikan. Mengingat permodalan merupakan permasalahan esensial karena aspek penting untuk menunjang operasionalisasi kegiatan produksi adalah ketersediaan modal yang diperoleh baik dari tabungan maupun pinajaman. Home industry merupakan permasalahan esensial yang akan disasar dari aktivitas pengelolaan modal dalam pengembangan kegiatan usaha oleh kelompok nelayan yang orientasi sasarannya adalah industri kuliner dengan pemberdayaan potensi laut sebagai bahan dasar produksi. Prospek indutri rumah tangga dinilai dapat memberdayakan wanita nelayan dalam perannya untuk menunjang perekonomian keluarga. Keberadaan warung lesehan dan ijin resmi sebagai substansi rumah industri adalah tujuannya untuk menumbuhkan semangat kewirausahaan yang sifatnya kolektif dari kelompok wanita nelayan secara produktif dan swadaya dengan program rintisan. Jadi, permasalahan prinsip yang perlu dicarikan solusinya adalah "hasil tangkapan ikan yang relatif tinggi untuk jenis ikan cakalan (tuna) belum mampu terfasilitasi oleh sarana permodalan yang cukup yang dapat menunjang pengembangan produktifitas produksi industri rumah tangga dari wanita nelayan yang berupa hasil tangkapan mentah maupun olehan kuliner yang pemasarannya bisa dilakukan secara terorganisir oleh kelompok wanita nelayan yang sifatnya kolektif., diantaranya dapat berupa: 1).Mendukung kehidupan masyarakat pedesaan khususnya kawasan pesisir Desa Tianyar Timur dengan meningkatkan kesempatan kerja, menyediakan penghidupan yang layak dan mantap bagi wanita nelayan, termasuk kelompok nelayan. 2).Meningkatkan produksi dan menjamin keamanan pangan dengan bahan dasar ikan laut di wilayah Desa Tianyar Timur. 3).Menghasilkan pangan yang terbeli dengan kualitas nutrisi tinggi dan 4).Melestarikan dan meningkatkan kualitas hidup di kawasan pesisir dan pedesaan Desa Tianyar Timur serta melestarikan sumber daya alam dan keanekaragaman hayati laut.

\section{METODE}

Identifikasi masalah menggunakan model eko-efesiensi (eco-development)

Berpedoman dari konsep ekoefesiensi (eco-development), maka tahapan kegiatan dalam model ini adalah melakukan identifikasi terhadap permasalahan yang dihadapi oleh kelompok wanita nelayan, perumusan program, dan pendanaan yang tersedia bagi kelompok wanita nelayan. Penerapan pendekatan ini berorientasi pada pembangunan ekonomi kerakyatan di kalangan kelompok wanita nelayan, adapun realisasi dari model pendekatan yang diterapkan dalam penyelenggaraan kegiatan P2M ini, kriteria yang dapat dipenuhi diantaranya yaitu:

a) Kelestarian Hasil

1) Potensi manfaat hasil laut berupa komoditi ikan diketahui dan dikelola dengan baik melalui kesepakatan bersama dan ketentuan kelompok yang tergabung dalam kelompok wanita nelayan yang keabsahannya berlaku antar generasi.

2) Jaminan keberlanjutan usaha pelaksanaan program $\mathrm{I}_{\mathrm{b}} \mathrm{M}$ Kelompok Wanita Nelayan, penindak lanjutannya 
diupayakan dan diatur melalui kesepakatan bersama dan ketentuan kelompok untuk dapat dibentuk sistem kewirausahaan dengan wadah Warung Lesehan yang bergerak di bidang hasil olahan aneka ragam hasil tangkapan ikan dan pengelolaannya dari kelompok wanita nelayan di Desa Tianyar Timur.

3) Kontrol penggerakan usaha dan pemanenan hasil tangkapan ikan yang akan diolah dan diproduksi menjadi produk dalam bentuk siap saji maupun kemasan pengurusan ijin usaha dan koordinasinya diupayakan dan diatur melalui kesepakatan bersama dan ketentuan kelompok kerjasama dengan Pemerintah Desa Tianyar Timur untuk pengurusan SIUP, dan Dinas Kesehatan untuk pengurusan standar dari B.POM.

b) Peningkatan Kesejahteraan

1) Keberadaan hasil tangkapan ikan mampu menopang kehidupan anggota kelompok secara terus menerus yang berlangsung antar generasi.

2) Dengan usulan program P2M, apabila disetujui pelaksanaannya diharapkan penyerapan tenaga kerja lebih meluas dan diorganisir sesuai kesepakatan dan ketentuan bersama.

3) Kelompok Nelayan yang di dalamnya tergabung kumpulan wanita nelayan mengorganisir anggotanya untuk bekerjasama sesuai dengan kesepakatan dan ketentuan bersama untuk membangun program wirausaha mandiri dari kalangan perempuan pesisir.

4) Terdapat pembagian tugas yang jelas dalam kelompok yang diatur dan disepakati melalui ketentuan bersama.

Pelaksanaan program dengan model Center for Environment and Society

Model Center for Environment and Society, didefinisikan sebagai suatu usaha berkelanjutan yang merupakan suatu cara memanfaatkan barang-barang alamiah dan jasa yang tidak merusak lingkungan dan memanfaatkan pengetahuan serta keterampilan para wanita nelayan yang pada akhirnya meningkatkan kemandirian dan kemampuan mereka. Model ini juga dapat diterapkan yaitu dengan memanfaatkan penggunaan secara produktif "social capital" atau modal sosial yaitu kemampuan orang untuk bekerjasama dalam memecahkan permasalahan-permasalahan nelayan dalam pengelolaan hasil tangkapan.

Unsur social capital yang dapat dijadikan faktor pendukung pelaksanaan program kegiatan pemberdayan kelompok wanita nelayan salah diantaranya meliputi; 1).pelestarian Nilai dan Kegotongroyongan. Adapun sub komponennya dalah sebagai berikut; a).Kegiatan gotong royong sebagai bagian dari kehidupan sehari-hari yang berlaku di kawasan pesisir Desa Tianyar Timur terutama yang melibatkan pemberdayaan kaum wanita nelayan. b).Pelanggaran atas nilai yang dianut akan menimbulkan sanksi yang bersifat mengikat sesuai dengan kesepakatan dan ketentuan bersama yang berlaku antar generasi. 2).Kelembagaan/institusi, meliputi; a).Filosofi kelembagaan terbatas pada laut sebagai bank kelompok atau unit sosial dengan ketentuan pengelolaan yang disepakati bersama hasil-hasilnya. b).Manajemen kelompok berperan dalam pemeliharaan dan pemanenan sesuai dengan kesepakatan bersama yang belaku dalam kelompok wanita nelayan tersebut.Kelembagaan yang lebih berperan adalah unit sosial masyarakat dengan ketentuan dan kesepakatan bersama yang disetujui bersama. c). Unit sosial yang dimaksudkan dalam hal ini adalah kelompok wanita nelayan Desa Tianyar Timur yang bergerak dalam bidang kewirausahaan dengan memanfaatkan hasil komoditi laut sebagai bahan produksi.

Pelaksanaan program dengan model enthrepreneurship capasity building (ECB) Model enthrepreneurship capasity building (ECB) terkait erat dengan kemampuan berwirausaha dari kelompok wanita nelayan, dengan model ini diharapkan: (1) memberikan wawasan, sikap, dan keterampilan usaha, (2) memberikan peluang, (3) memfasilitasi, dan (4) memonitor dan mengevaluasi (Kurana, 2008). Langkah penerapan model ini secara riil di lapangan oleh tim pengusul P2M terhadap mitra kelompok wanita nelayan, diantaranya akan diterapkan sebagai berikut:

1. Pelatihan dan pembinaan di bidang industri keterampilan wanita nelayan desa Tianyar Timur dibantu oleh staf dosen 
yang tergabung dalam tim pengusul program

Untuk menunjang program $\mathrm{I}_{\mathrm{b}} \mathrm{M}$ Kelompok Wanita Nelayan Desa Tianyar Timur di bidang kuliner dengan program kewirausahaan pengembangan produk kuliner baik yang siap saji maupun kemasan, tentunya wanita nelayan Desa Tianyar Timur harus memiliki keterampilan mengolah komoditi ikan laut sebagai industri rumah tangga yang memiliki prospek ekonomis untuk dipasarkan. Umumnya wanita nelayan yang tergabung dalam kelompok sudah memiliki keterampilan seperti membuat Pesan $\mathrm{Be}$ Pasih, Marus Be Pasing, Gerang, ikan pindang, asap, abon, kerupuk dan Bakwan Be Pasih yang merupakan jenis makanan yang siap saji. Melalui program ini juga akan diurus mengenai surat ijin usaha perdangan (SIUP), dan standarisasi dari BPOM untuk kemasannya dan batas waktu pengkonsumsian dari standarisasi hygiene and sanitation.

2. Pembangunan sebuah Warung Lesehan lengkap dengan surat ijin usaha perdagangan (SIUP) dari Pemerintah Desa Tianyar Timur untuk operasionalisasi kegiatan kewirausahaan yang akan dikembangkan oleh kelompok wanita nelayan Desa Tianyar Timur. Warung Lesehan ini nantinya diharapkan merupakan wadah dari kelompok wanita nelayan dalam mengembangkan kreatifitas kuliner yang dilatihkan. Di samping itu, lesehan sebagai tempat penjualan kuliner laut khas Desa Tianyar Timur, keberadaan lesehan dapat pula merangkap sebagai stan untuk memasarkan produk kemasan seperti abon, asinan ikan, tepung tcara pembuatannya telah dilatihkan dengan koordinasi dari Dosen Tata Boga Jurusan PKK.

3. Model kemasan/sistem packing produk yang diberikan oleh BPOM harus melakukan uji kelayakan standarisasi mutu pangan yang akan dipasarkan dari hasil produk kelompok wanita nelayan Desa Tianyar Timur. Pihak terkait yang akan dilibatkan untuk koordinasi kegiatan ini adalah Puskesmas setempat, yang selanjutnya apabila program dapat ditindaklanjuti pengurusan kemasan produk nantinya dapat dikoordinasikan lebih lanjut ke pihak terkait yang berada di tataran wilayah kabupaten/kota Karangasem.

4. Jenis produk yang dipasarkan meliputi, Sate Pasih, Pesan, Marus, Gerang, Bakwan Be Pasih, abon, ikan pindang, kerupuk dan produk unggulan yang diharapkan dapat dipasarkan ke luar daerah sebagai produksi unggulan adalah tepung tulang ikan dengan label khusus dari BPOM Bali dan sekaligus menunjuk identitas Desa Tianyar Timur sebagai ikon desa bahari dengan pemberdayaan perempuan pesisir yang tergabung dalam kelompok wanita nelayan terorganisir.

5. Peningkatan kualitas sumber daya manusia (SDM) perempuan pesisir Desa Tianyar Timur

Dalam rangka peningkatan kualitas sumber daya manusia. Staf dosen Undiksha yang berlatar belakang kehlian bidang Budidaya Kelautan dan Perikanan merancang beberapa program antara lain penyuluhan secara kontinu dan intensif terhadap seluruh kelompok wanita nelayan yang dijadikan mitra, program pendidikan latihan teknis pembangunan budi daya kelautan; studi banding dan evaluasi/pembinaan terhadap usaha perempuan pesisir; studi banding dan evaluasi/pembinaan terhadap perempuan pesisir melalui lomba praktek kuliner di tingkat Kecamatan Kubu. Di samping itu, juga dirancang melalui pelaksanaan job training dengan Jurusan Budidaya Kelautan Undiksha. Sisi lain dari kualitas sumber daya manusia yang ditingkatkan pada perempuan pesisir tentang pembangunan kawasan pesisir adalah kemampuan membuat perencanaan teknis kegiatan melalui pelaksanaan lokakarya di tingkat Desa, Kecamatan, dan Kabupaten.

Dalam rangka meningkatkan efesiensi dan efektifitas serta percepatan peningkatan kualitas sumber daya manusia khususnya perempuan pesisir, maka dilakukan pendampingan dan penyuluhan yang dilakukan oleh penyuluh lapangan Kelautan dan Perikanan Kabupaten maupun LSM serta instansi lain yang mempunyai komitmen besar terhadap pengembangan komoditi laut/pesisir. Khusus untuk penyuluh Kelautan dan Perikanan Kabupaten 
Karangasem dalam rangka pelaksanaan pendampingan maupun penyuluhan ditetapkan wilayah kerja yang jelas dari masing-masing penyuluh.

Skema transfer Ipteks kepada mitra sebagai berikut:

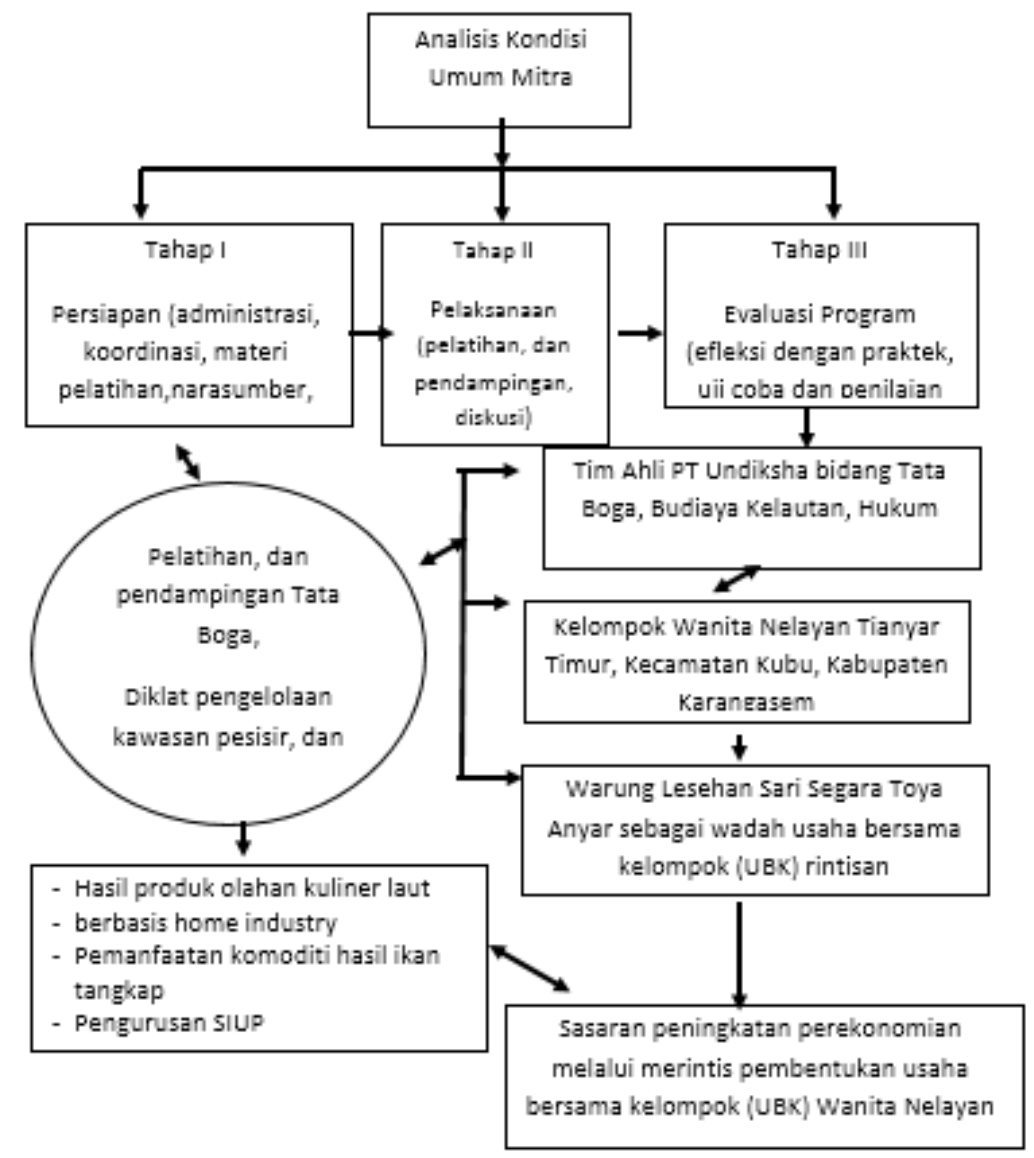

KARYA UTAMA

keberhasilan kegiatan yang telah dilakukan, maka akan dilakukan evaluasi minimal 3 (tiga) kali, yaitu evaluasi proses, evaluasi akhir, dan evaluasi tindak lanjut. Kegiatan evaluasi ini akan melibatkan tutor/pakar dari Undiksha Singaraja. Kriteria dan indikator pencapaian tujuan dan tolak ukur yang digunakan untuk menjastifikasi tingkat keberhasilan kegiatan dapat diuraikan pada tabel berikut :

Tabel 01. Indikator Keberhasilan Program IbM Wanita Nelayan Tianyar Timur Tahun 2014.

\begin{tabular}{|c|c|c|c|c|c|}
\hline No & Jenis Data & $\begin{array}{c}\text { Sumber } \\
\text { Data }\end{array}$ & Indikator & $\begin{array}{c}\text { Kriteria } \\
\text { Keberhasilan }\end{array}$ & Instrumen \\
\hline 1. & $\begin{array}{l}\text { Pengetahuan } \\
\text { tentang } \\
\text { pengolahan } \\
\text { bahan baku hasil } \\
\text { tangkapan ikan } \\
\text { menjadi produk } \\
\text { olahan kuliner } \\
\text { lesehan, diklat } \\
\text { pengelolaan } \\
\text { kawasan pesisir, } \\
\text { dan pelatihan }\end{array}$ & $\begin{array}{l}\text { Wanita } \\
\text { Nelayan } \\
\text { Tianyar } \\
\text { Timur }\end{array}$ & $\begin{array}{l}\text { Pengetahuan } \\
\text { Wanita } \\
\text { Nelayan } \\
\text { Tianyar Timur }\end{array}$ & $\begin{array}{l}\text { Terjadi perubahan } \\
\text { yang positif } \\
\text { terhadap } \\
\text { pengetahuan } \\
\text { pengolahan } \\
\text { bahan baku hasil } \\
\text { tangkapan ikan } \\
\text { menjadi produk } \\
\text { olahan kuliner } \\
\text { lesehan, diklat } \\
\text { pengelolaan }\end{array}$ & $\begin{array}{l}\text {-Praktek } \\
\text { pengolahan } \\
\text { produk } \\
\text { pengolahan } \\
\text { bahan baku } \\
\text { hasil tangkapan } \\
\text { ikan menjadi } \\
\text { produk olahan } \\
\text { kuliner lesehan, } \\
\text { diklat } \\
\text { pengelolaan }\end{array}$ \\
\hline
\end{tabular}




\begin{tabular}{|c|c|c|c|c|c|}
\hline No & Jenis Data & $\begin{array}{c}\text { Sumber } \\
\text { Data }\end{array}$ & Indikator & $\begin{array}{c}\text { Kriteria } \\
\text { Keberhasilan }\end{array}$ & Instrumen \\
\hline & $\begin{array}{l}\text { pengurusan ijin } \\
\text { usaha } \\
\text { perdagangan }\end{array}$ & & & $\begin{array}{l}\text { kawasan pesisir, } \\
\text { dan pelatihan } \\
\text { pengurusan ijin } \\
\text { usaha } \\
\text { perdagangan }\end{array}$ & $\begin{array}{l}\text { kawasan pesisir, } \\
\text { dan pelatihan } \\
\text { pengurusan ijin } \\
\text { usaha } \\
\text { perdagangan }\end{array}$ \\
\hline 2. & $\begin{array}{l}\text { Pengetahuan } \\
\text { tentang } \\
\text { keterampilan tata } \\
\text { boga, pengelolaan } \\
\text { kawasan pesisir, } \\
\text { dan pengurusan } \\
\text { ijin usaha }\end{array}$ & $\begin{array}{l}\text { Wanita } \\
\text { Nelayan } \\
\text { Tianyar } \\
\text { Timur }\end{array}$ & $\begin{array}{l}\text { Pengetahuan } \\
\text { Wanita } \\
\text { Nelayan } \\
\text { Tianyar Timur }\end{array}$ & $\begin{array}{l}\text { Terjadinya } \\
\text { perubahan yang } \\
\text { positif } \\
\text { pengetahuan } \\
\text { Wanita Nelayan } \\
\text { Tianyar Timur } \\
\text { tentang tata boga, } \\
\text { pengelolaan } \\
\text { kawasan pesisir, } \\
\text { dan pengurusan } \\
\text { ijin usaha }\end{array}$ & $\begin{array}{l}\text { Pelatihan dan } \\
\text { praktek } \\
\text { langsung }\end{array}$ \\
\hline
\end{tabular}

Keseluruhan proses transfer iptek ini dilaksanakan dengan pola pelatihan dan pendampingan terhadap Wanita Nelayan Tianyar Timur yang meliputi: Tata Boga, Pengelolaan Kawasan Pesisir, Prosedur dan Tata Cara Pengurusan Ijin Usaha. Pelatihan dengan pendampingan terhadap proses produksi, pengelolaan kawasan pesisir, tata cara pengurusan ijin usaha, sehingga diharapkan kegiatan P2M yang diselenggarakan dapat menyasar penguasaan pengetahuan dan keterampilan Kelompok Wanita Nelayan Tianyar Timur secara berkesinambungan.

\section{ULASAN KARYA}

Pelaksanaan kegiatan Pengabdian kepada Masyarakat "IbM Kelompok Wanita Nelayan Tianyar Timur dilaksanakan selama 6 (enam) bulan, dimulai dari 19 Mei sampai dengan 07 Nopember 2014 yang telah dilaksanakan $100 \%$ program yaitu: pelatihan produksi olahan kuliner laut berbahan baku hasil tangkapan ikan masyarakat pesisir desa Tianyar Timur, diklat pengelolaan kawasan pesisir, pengurusan ijin usaha perdagangan, pendampingan kelompok dalam hal pengelolaan kawasan pesisir dan pengurusan ijin usaha perdagangan.Untuk menyukseskan penyelenggaraan program tidak terlepas dengan prosedur birokrasi yang dilakukan oleh tim pelaksana dari Universitas Pendidikan Ganesha (UNDIKSHA).
Alur birokrasi pelaksanaan program dengan mendatangi langsung desa tujuan P2M dan bersilaturahmi dengan aparatur desa setempat. Adapun hasil koodinasi tim dengan birokrasi Pemerintahan Desa Tianyar Timur, diantaranya: kesepakatan jadwal kegiatan, tempat penyelenggaraan, agenda kegiatan, termasuk pedataan peserta pelatihan dari masing-masing dusun di desa Tianyar Timur dikoordinir oleh Bagian Kesejahteraan Masyarakat desa Tianyar Timur, yaitu Ibu Ni Luh Witarsih yang pada saat koordinasi mendampingi Bapak Perbekel Tianyar Timur Bapak I Gede Suadi, SH.

Program yang kami rancang dan usulkan untuk diselenggarakan di desa Tianyar Timur memperoleh apresiasi yang sangat luar biasa dari Pemerintah Desa setempat beserta jajarannya. Mengingat baru pertama kali desa Tianyar Timur disasar kegiatan pengabdian dengan melibatkan warga masyarakat untuk mampu diberdayakan melalui kegiatan sosialisasi dan pelatihan dari pihak LPM UNDIKSHA.

Dipilinnya sasaran Wanita Nelayan, selain merupakan kelompok masyarakat yang rutinitasnya identik dengan keterlibatannya dalam proses pengembangan dan pemberdayaan kaum perempuan desa, juga merupakan masyarakat yang memiliki tingkat produktivitas mobilisasi yang tinggi dalam penyebar luasan informasi, terutama yang 
berkaitan dengan wawasan pengetahuan dan keterampilan yang wanita nelayan peroleh pada saat penyelenggaraan program P2M. P2M tahap I dilaksanakan pada bulan September tepatnya Minggu, 15 Juni 2014 di rumah koordinator wanita nelayan desa Tianyar Timur yang akan dimanfaatkan losnya untuk pendirian warung lesehan, dengan mendatangkan tim pakar dari Undiksha Singraja dengan kualifikasi akademik, diantaranya Tata Boga, Budidaya Kelautan, dan Hukum).

$$
\text { Untuk mengukur tingkat }
$$

keberhasilan kegiatan yang telah dilakukan, maka akan dilakukan evaluasi minimal 3 (tiga) kali, yaitu evaluasi proses, evaluasi akhir, dan evaluasi tindak lanjut. Kegiatan evaluasi ini akan melibatkan tutor/pakar dari Undiksha Singaraja. Kriteria dan indikator pencapaian tujuan dan tolak ukur yang digunakan untuk menjastifikasi tingkat keberhasilan kegiatan

Setelah diberikan pelatihan oleh tim pelaksana dari Undiksha Singaraja, Wanita Nelayan Tianyar Timur Kecamatan Kubu dapat memahami dengan jelas materi pelatihan mengenai tata boga dalam hal mengolahan hasil tangkapan ikan yang semula keterampilan mengolahnya tidak dikuasai dan sekarang menjadi dikuasai dapat dipraktekannya menjadi beragam jenis olahan produk hasil karya olahan kuliner yang telah dilakukan pendampingan dari pihak tim pelaksana IbM Kelompok Wanita Nelayan Tianyar Timur. Diklat pengelolaan kawasan pesisir yang diselenggarakan bertujuan untuk menunjang tingkat pengetahuan dan wawasan nelayan tentang pemberdayaan kawasan pesisir secara tepat guna. Prosedur dan tata cara pengurusan ijin juga dilatihkan kepada wanita nelayan Tianyar Timur untuk memberikan bekal tentang pengurusan ijin usaha baik yang sifatnya individu maupun kelompok. Pengurusan ijin penting karena nantinya Wanita Nelayan Tianyar Timur dapat menggunakan SIUP yang dimiliki sebagai agunan simpan pinjam di LPD maupun BRI terdekat di tingkat Kecamatan.

Keunggulan yang dapat dilihat dali pelaksanaan program, bahwa berdasarkan hasil evaluasi tidak lanjut juga terekam, beberapa manfaat praktis yang diperoleh oleh Wanita Nelayan Tianyar Timur Kecamatan Kubu melalui Pelatihan Tata Boga, Pengelolaan Kawasan Pesisir, Prosedur dan Tata Cara Pengurusan Ijin Usaha, yaitu: (1) mereka mendapatkan informasi yang jelas dan utuh mengenai hakekat pemberdayaan masyarakat dari segi pengetahuan dan keterampilan, bermakna untuk penciptaan lapangan pekerjaan baru yang sifatnya inovatif dari pengembangan warung lesehan laut; (2) Wanita Nelayan Tianyar Timur yang menjadi peserta pelatihan memperoleh gambaran yang jelas mengenai langkah pengembangan iklim usaha dengan memanfaatkan komoditas hasil tangkapan ikan secara swadaya; (3) peserta pelatihan juga mendapatkan gambaran yang jelas dan utuh tentang manfaat hasil tangkapan ikan apabila dikelola dengan baik akan mendatangkan nilai finansial apabila telah diolah menjadi aneka olahan kuliner laut sebagai menu handalan lesehan Sari Segara Toya Anyar.

Kegiatan tahap akhir program yang akan dilaksanakan dalam program pengabdian kepada masyarakat "IbM Kelompok Wanita Nelayan Tianyar Timur" pada kelompok ini adapun kegiatan pendampingan dan evaluasi yang meliputi:

1. Pendampingan pendidikan dan pelatihan Perancangan alat usaha untuk melengkapi perkakas los lesehan yang masih kosong.

2. Diklat pengelolaan kawasan pesisir desa Tianyar dalam hal pengelolaan hasil bahari dan pemberdayaan masyarakat pesisir yang disinergikan dengan pembangunan berwawasan lingkungan

3. Penataan los oleh kelompok wanita nelayan untuk pengkondisian tempat usaha layak pakai.

4. Pelatihan tata boga, melakukan pengolahan potensi laut terutama hasil tangkapan ikan untuk bisa dihasilkan berbagai olahan kuliner dengan cita rasa khas Tianyar.

5. Pendampingan manajemen produksi dan kewirausahaan sehingga terdapat tertib administrasi pembukuan dan keuangan kelompok yang diharapkan 
mampu menjadikan kelompok terus berkembang ke arah yang lebih baik

6. Pendampingan pengurusan SIUP UBK berupa Identitas Kelompok"Warung Lesehan Sari Segara Toya Anyar" sampai mendapatkan pengakuan dan ketetapan hukum

7. Evaluasi program untuk melihat seberapa jauh program ini bermanfaat bagi kelompok wanita nelayan Tianyar Timur

Dengan sisa waktu yang tersedia dari bulan Juli- Nopember tim pelaksana P2M telah berhasil merampungkan ketujuh hal tersebut dalam pelaksanaan program pengabdian pada masyarakat yang dilaksanakan pada kelompok wanita nelayan Tianyar Timur.

Ke tujuh hal tersebut sudah dapat dilaksanakan dalam pelaksanaan program pengabdian pada masyarakat yang dilaksanakan pada Kelompok wanita nelayan Tianyar Timur yang menyasar aspek pemberdayaan pengetahuan dan keterampilan.

Kendala pelaksanaan program adalah sulitnya meminid waktu untuk pencapaian kesepakatan pelaksanaan kegiatan, karena umumnya peserta latihan terbentur dengan rutinitas pekerjaan harian yang menunjang perekonomian keluarga, maupun pelaksanaan kegiatan ritual adat-istiadat yang lumayan padat di desa Tianyar Timur dalam kaitannya dengan paruman desa adat untuk penyelenggaraan ritual keagamaan sebagaimana layaknya masyarakat Hindu Bali pada umumnya. Jadi, untuk bisa mengkoordinir warga perlu koordinasi intensif dengan pihak kesra dan segenap jajarannya.

Berkaitan dengan pengkondisian peserta program, walaupun dijumpai kendala masalah waktu selama tim pelaksana program mampu mengatasinya dengan melakukan koordinasi secara intensif dengan Perbekel Desa Tianyar Timur, staf Kesra desa Tianyar Timur, dan segenap jajaran terkait yang pada saat tahap evaluasi kegiatan memfasilitasi tim pelaksana dari segi tempat yang berupa los warung lesehan untuk dimanfaatkan sebagai tempat uji coba untuk melakukan praktek evaluasi hasil pelaksanaan kegiatan.

\section{KESIMPULAN}

Kesimpulan yang dapat diperoleh dari pelaksanaan program pengabdian kepada masyarakat "IbM KelompokWanita Nelayan Tianyar Timur" di Banjar Dinas Eka Adnyana, Tianyar Timur, Kecamatan Kubu, Kabupaten Karangasem, , adalah:

(1) Tingkat partisipasi yang tinggi dari mitra program pengabdian kepada masyarakat memberikan dampak positif bagi pelaksanaan program, terlihat dari pelatihan pembuatan alat penunjang usaha, penataan los, diklat produksi dan kewirausahaan, pelatihan tata boga, dan rancangan pengurusan SIUP UBK dapat berjalan dengan baik

(2) Pelaksanaan program mampu menghasilakan luaran-luaran yang diharapkan oleh program pengabdian kepada masyarakat ini, kecuali pengurusan SIUP UBK "Warung Lesehan Sari Segara Toya Anyar" masih harus melalui proses pendaftaran.

\section{DAMPAK DAN MANFAAT KEGIATAN}

Adapun dampak yang diperoleh dari program pengabdian ini adalah manfaat hasil bagi mitra dan desa terkait, diantaranya sebagai berikut:

1. Tingkat partisipasi yang tinggi dari mitra program pengabdian kepada masyarakat memberikan dampak positif bagi pelaksanaan program, terlihat dari pelatihan dan pendampingan tata boga berbahan baku hasil tangkapan ikan, diklat pengelolaan kawasan pesisir, dan tata cara pengurusan ijin usaha perdagangan dapat berjalan dengan baik

2. Pelaksanaan program mampu menghasilkan luaran-luaran yang diharapkan oleh program pengabdian kepada masyarakat ini, kecuali surat ijin usaha perdagangan "Warung Lesehan Sari Segara Toya Anyar" masih harus diurus karena jenis usaha kelompok yang akan dikelola masih dalam taraf rintisan untuk dikembangkan sehingga perlu tahapan-tahapan administrasi melalui proses pendaftaran yang harus dipenuhi dan disepakati secara kolektif 
antar pengurus terlebih dahulu. Manfaat dari terselenggaranya program pengabdian ini adalah tingginya kreatifitas kelompok wanita nelayan Tianyar Timur dalam memproduksi produk-produk kreatif olahan hasil tangkapan ikan diharapkan mendapatkan perhatian khusus, sehingga menjadi keberlanjutan program dari kegiatan "IbM Kelompok Wanita Nelayan Tianyar Timur" yang saat ini hanya sampai pada produksi bahan olahan kuliner laut, publikasi dan promosi keberadaan warung lesehan Sari Segara Toya Anyar melalui blog resmi akan diupayakan secara lebih lanjut melalui pendampingan tim. Bagi wanita nelayan sebagai informan kunci penyebarluasan informasi di desaTianyar Timur, hendaknya mempu memberdayakan hasil pengetahuan dan keterampilan yang diperoleh dari kegiatan P2M bagi masyarakat luas.

Bagi pihak terkait, yang dalam hal ini Pemerintah Desa Tianyar Timur, diharapkan dapat memberikan dukungan kemudahan kebijakan dan berbagi pengalaman dari segi wawasan pengetahuan yang ditransfer ke wanita nelayan guna menyukseskan rintisan program usaha industri rumah tangga yang telah digagas secara kolektif tersebut. Tingginya kreatifitas kelompok wanita nelayan Tianyar Timur dalam mengolah hasil tangkapan ikan menjadi hasil olahan kuliner bahari kreatif diharapkan mendapatkan perhatian khusus, sehingga menjadi keberlanjutan program dari kegiatan "IbM Kelompok Wanita Nelayan Tianyar Timur" yang saat ini masih dirintis pendirian dan keberlanjutan perkembangannya.

\section{DAFTAR PUSTAKA}

Dasman, Raymon. 1980. Prinsip Ekologi Untuk Pembangunan, Terjemahan Idjah Soemarwoto. Jakarta: Gramedia.

Gerungan. 1988. Psikologi Sosial. Bandung: Unesco.

Karama dan Abdurrachman. 1995. Kebijakan Nasional dalam Penanganan Lahan Kritis di
Indonesia. Yogyakarta: BPTP Prosiding Seminar Rekayasa Teknologi Konservasi.

Kurana. 2008. Sukses Mengembangkan Wirausaha. Jakarta: Grsindo.

Kurniasih Dian. 2006. Pengaruh Daya Dukung Lahan dan Faktor Sosial Ekonomi terhadap Perilaku Petani dalam Konservasi Lahan Pertanian di Kabupaten Kulon Progo. Yogyakarta: Program Studi Ekonomi Pertanian, Jurusan IImu-IImu Pertanian, UGM.

Muhadjir, N. 1993. Kepemimpinan Adopsi Inovasi untuk Pengembangan Masyarakat. Yogyakarta: Rake Press.

Negara Republik Indonesia. UndangUndang Nomor 5 Tahun 1999 tentang Larangan Praktek Monopoli dan Persaingan Usaha Tidak Sehat. Lembaran Negara Nomor 33, TLN RI Nomor 3817.

Pemerintah Kabupaten Karangasem. Data Statistik Desa Tianyar Tahun 2011. Karangasem: Tianyar.

Suhardjo. 1988. Peranan Kelembagaan dalam Hubungannya dengan Komersialisasi Usahatani dan Distribusi Pendapatan Wilayah Kabupaten Banjar Negara Jawa Tengah. Disertasi (tidak dipublikasikan). Yogyakarta: UGM.

Soemarwoto, Otto. 2001. Ekologi, Lingkungan Hidup, dan Pembangunan. Jakarta: Penerbit Djambatan.

Susanto, P.Astrid. 1983. Pengantar Sosiologi dan Perubahan Sosial. Jakarta: Bina Cipta. 